\title{
Art Reproduction and the Nation: National Perspectives in an International Art Market
}

\author{
Robert Verhoogt
}

During the nineteenth century the business of reproducing artworks was booming internationally. New (photo)graphic techniques like aquatint, steel engraving, lithography and photography were quickly developing to reproduce paintings and drawings effectively in countless prints and photographs. This was also made possible thanks to new printing presses, innovative paper production and modern means of distribution and communication. It resulted in the wide-ranging production of illustrated magazines, journals and prints, including art reproductions. Artists, printmakers and art dealer-publishers provided an international distribution to an expanding worldwide public of consumers of art and reproductions. Internationally oriented art dealerpublishers like John Boydell, Franz Hanfstaengl, Thomas Agnew \& Sons, Ernest Gambart, Colnaghi \& Sons, Goupil \& Cie and Buffa \& Sons were, as Jeremy Maas stated in his biography of the Victorian art dealer-publisher Ernest Gambart, 'the un-acknowledged legislators of the art world. It was they who carried an artist's reputation into every home in the country and to all the four corners of the globe.'

In his classic work An Inquiry into the Nature and Causes of the Wealth of Nations (1776), Adam Smith strongly advocated the free market ruled by the invisible hand of supply and demand with only limited state intervention. Smith's economic theory was inspired by the Industrial Revolution, which in turn was accelerated by his new ideas regarding production, consumption and the division of labour. The Industrial Revolution affected all aspects of society in the eighteenth and nineteenth centuries, including the art world and the printing industry. Concerning the world of art, Smith advised the state to stimulate the arts 'by encouraging, that is, by giving entire liberty to all those who, from their own interest, would attempt, without scandal or indecency, to amuse and divert the people by painting, poetry, music, dancing; by all sorts of dramatic representations and exhibitions; would easily dissipate, in the greater part of them, that melancholy and gloomy humour which is almost always the nurse

1 Jeremy Maas, Gambart: Prince of the Victorian Art World (London: Barrie \& Jenkins, 1975), 28.

(C) ROBERT VERHOOGT, 2019 | DOI:10.1163/9789004291997_011

This is an open access chapter distributed under the terms of the prevailing CC-BY-NC License at the time of publication. 
of popular superstition and enthusiasm.'2 Smith's principles for a free market economy were widely disseminated around 1800 through various translations of his Wealth of Nations. ${ }^{3}$ Influential economists like David Ricardo (1772-1832) and John Stuart Mill (1806-73) adapted his ideas about transforming the economy from the national protectionism seen during the Napoleonic Wars toward a more open economy inspired by ideas of liberalism and free trade. The French economist Jean-Baptiste Say also supported the ideas expressed by Smith in his Traite de l'économie politique (1803), but his advocacy to end state intervention was only partially followed in France, where the invisible hand of the government seems stronger than elsewhere. ${ }^{4}$

The process of internationalisation of the markets that logically followed from liberal economic policies was, of course, a gradual one. For one thing, it was often kept in check by, and even in collision with, national interests and nationalist modes of thinking. But nationalism and internationalism could also mutually reinforce one another. They were, in other words, both conflicting and interlocking forces in the development of nineteenth-century markets, including the print market.

Throughout the nineteenth century, local print dealers became more and more connected to the international art market. At the same time this international art market remained richly coloured by divergent national socio-economic and cultural contexts, national interests of various natures and nationalist modes of thinking, which could involve institutions, art dealers, publishers, artists, collectors and critics alike. Of course, "nation," "national," and "nationalism" are complex concepts referring to ever-changing cultural identities and political entities during the nineteenth century, dictated by wars and revolutions. ${ }^{5}$ That does not take away, however, any of the importance or reality that these concepts, and the ways of thinking that depended on them, had for actors operating in the market: nationality and national differences,

2 Adam Smith, An Inquiry into the Nature and Causes of the Wealth of Nations, ed. Salvio M. Soares (MetaLibri Digital Library, 2007), 614.

3 Robert L. Heilbroner, The Worldly Philosophers: The Lives, Times and Ideas of the Great Economic Thinkers (London: Touchstone, 2000), 67.

4 Jeff Rosen, "The Political Economy of Graphic Art Production during the July Monarchy," Art Journal 48 (1989): 41.

5 Nationalism proved to be a fascinating topic for scientific research in political science, anthropology and linguistic theory, as can be learned from the modern classic publications by Eric Hobsbawm and Benedict Anderson. See: Benedict Anderson, Imagined Communities: Reflections on the Origin and Spread of Nationalism (London: Verso 2006); Eric Hobsbawm, Nations and Nationalism since 1780 (Cambridge: Cambridge University Press, 1992). In 1991 Anderson stated in the preface to his second edition: "The study of nationalism too has been startlingly transformed—in method, scale, sophistication, and sheer quality' (p. xii). 
both perceived and actual, were a practical reality that these figures had to take into account in the organisation of their businesses and include in their strategic calculations.

In this chapter I will examine three different ways in which the print market was shaped by the forces of nationalism and internationalism. I will first reflect on the issue of copyright legislation, the legal basis for artists and dealers in the business of art reproduction. During most of the nineteenth century, copyright legislation was nationally oriented, but differences between national legislation obstructed the international expansion of the market. Eventually, it became necessary to eliminate these differences and regulate the art and print business through international copyright law. Second, I will shift my focus toward individual art dealer-publishers and their use of nationalist ideology in the marketing of their products. As the nineteenth century progressed, national "schools" of engraving were often threatened by the wide supply of cheap prints from abroad, which made publishers turn towards the state for national patronage and promote their products as "authentic" national publications. Here, we have the opposite constellation of the national and the international, wherein foreign imports threaten the local market and give rise to nationalist protectionism. Finally, I will examine the Dutch art dealerpublisher Frans Buffa and his strategies to reconcile his "national" merchandise with the foreign expansion and gradual integration of markets. In Buffa's business model, the national and international are no longer at odds but are dialectically reconciled and mutually reinforce one another to stimulate market growth. The national could, therefore, not only complicate or hamper the internationalisation of the market or remedy negative effects of this process of internationalisation, but it could also stimulate the market's international expansion.

This essay is based on my research for Art in Reproduction: NineteenthCentury Prints after Lawrence Alma-Tadema, Jozef Israëls and Ary Scheffer (AUP, 2007), with elaboration on art reproduction in relation to national perspectives in the nineteenth-century art world. I do not contest the international scale and development of the art business in the nineteenth century, but rather I intend to complement this picture. As James Hamilton explains in his recent inspiring book, A Strange Business: Making Art and Money in Nineteenth Century Britain (2014), the artist William Turner once stated that painting is 'a strange business. ${ }^{6}$ Art reproduction closely intermingled in this strange international

6 James Hamilton, A Strange Business: Making Art and Money in Nineteenth-Century Britain (London: Atlantic Books, 2014), 4. 
business without borders, but it can be considered through national perspectives as well.

\section{National Copyright Protection}

In his pamphlet On Piracy of Artistic Copyright (1863), art dealer-publisher Ernest Gambart emphasised the importance of copyright protection by the state: 'It is not, [...] against competition that protection for copyright in artworks is demanded, [...] but against robbers. ${ }^{7}$ During the 1850 os and 1860 , Gambart and other publishers took many photographers to court. Once a popular painting had been photographed by fraudulent photographers, the publisher of an engraving after the original work lost his business. ${ }^{8}$ Gambart instigated more than twenty lawsuits concerning William Holman Hunt's world-famous painting The Light of the World alone. ${ }^{9}$ Gambart stated: 'It is now a question for the legislature and the public to decide whether or not the school of English line engraving, once occupying so high a position, shall perish or be maintained. ${ }^{\prime 10}$ Gambart was responding to large-scale, illegal reproduction with a passionate plea to improve copyright protection.

Copyright laws were developed by national authorities influenced by nationally oriented cultural and legal ideas of property and authorship. ${ }^{11}$ The legal protection of the (visual) artist was first advocated by the painter and engraver William Hogarth, famous for his series of paintings, such as A Rake's Progress (1732-33), and their many printed reproductions (Fig. 9.1). Battling

7 Ernest Gambart, On Piracy of Artistic Copyright (London: William Tegg, 1863), 4. See also: Anon., "Copyright in Sculpture," The Art Journal (1863): 59; Anon., "Reviews," The Art Journal (1863): 128.

8 William Holman Hunt, Pre-Raphaelitism and the Pre-Raphaelite Brotherhood, vol. 2 (London: Macmillan, 1905), 96.

9 Anon., "Copyright in Art," The Art Journal (1862): 241; Anon., "Infringement of Copyright," The Art Journal (1863): 103; Anon., "Infringement of Copyright," The Art Journal (1863): 210-1; Anthony J. Hamber, 'A Higher Branch of the Art': Photographing the Fine Arts in England, 1839-1880 (Amsterdam: Gordon and Breach, 1996), 12-3.

10 Maas, Gambart, 21. See for more about nineteenth-century copyright laws in relation to art reproduction: Robert Verhoogt, Art in Reproduction: Nineteenth-Century Prints after Lawrence Alma-Tadema, Jozef Israëls and Ary Scheffer (Amsterdam: Amsterdam University Press, 2007), 150-79.

11 Robert Verhoogt and Chris Schriks, "Reflecting Media: A Cultural History of Copyright and the Media," in The Handbook of the History of Information Security, eds. Karl de Leeuw and Jan Bergstra (Amsterdam: Elsevier Science, 2007), 83-119. The English copyright system was founded by Queen Anne's Act of 1710 in which the (literary) author was recognised for the first time. Act 8 Anne, c.19. 


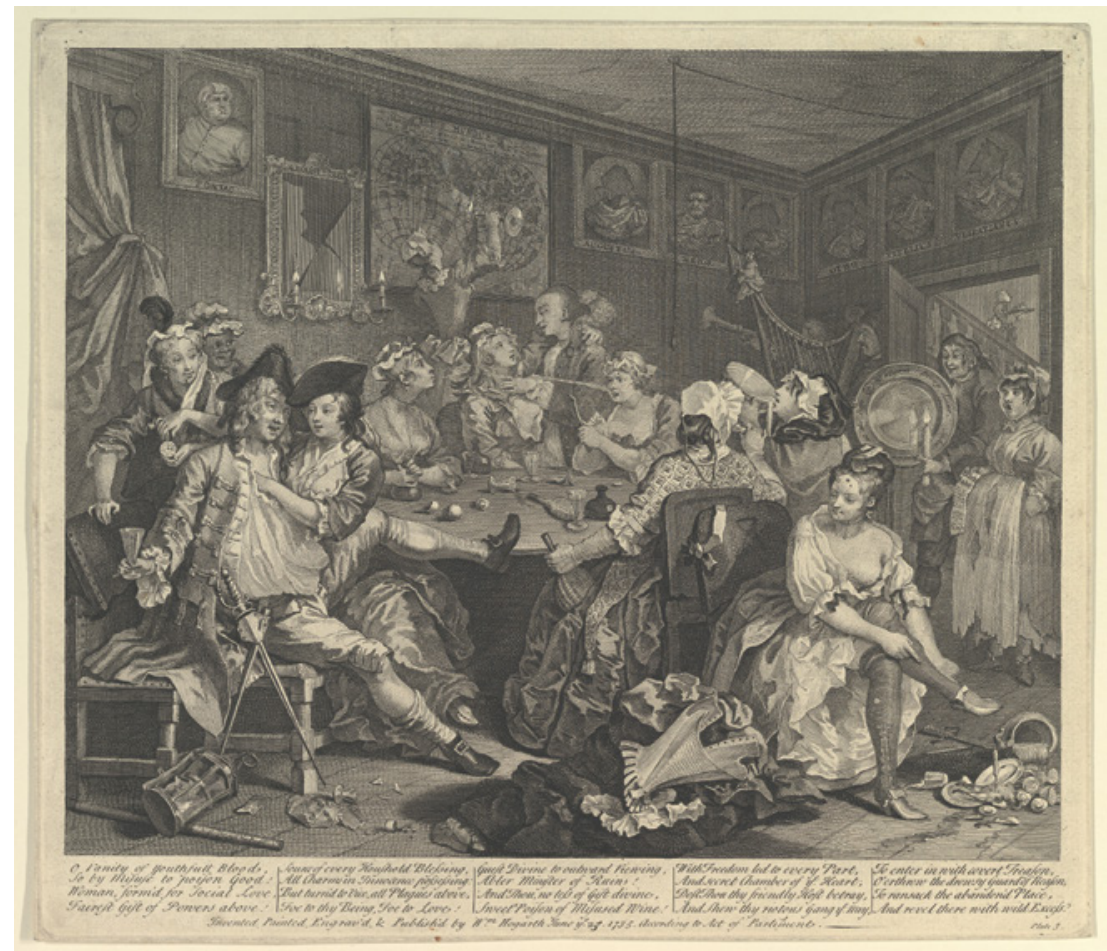

FIG URE 9.1 William Hogarth, A Rake's Progress, Plate 3, 25 June 1735. Etching and engraving, third state of three, $35.5 \times 40.9 \mathrm{~cm}$. New York, The Metropolitan Museum of Art, Gift of Mrs. Carl Joseph Ulmann

the powerful publishers, Hogarth strongly proclaimed that he should be the primary party entitled to exploit his work and earn benefits from it. His efforts were eventually rewarded with the Engraving Copyright Act of 24 June 1735, better known as the 'Hogarth Act,' which provided artists and printmakers 'the sole right and liberty of printing and reprinting the same for the term of fourteen years, to commence from the day of the first publishing thereof.' ${ }^{\prime 2}$ This British legal protection was gradually extended. ${ }^{13}$ The 1862 Copyright Act was an important step in the development of modern British copyright law concerning the visual arts, although the English copyright remained a legal

12 Act 8 Geo.2, c.13.

13 The Hogarth Act, and its 1767 amendment, offered protection to the makers of engravings, etchings, mezzotints and lithographs: See: 15 Vict.c.12 art. XIV in Charles Palmer Phillips, The Law of Copyright in Works of Literature and Art and in the Application of Designs (London: V\&R Stevens, Sons and Haynes, 1863), lxxviii. 
patchwork of rules concerning literature, printmaking, painting, sculpture and applied arts. ${ }^{14}$

'Come to France, and travel from Calais to Marseilles, and you will not find any pirated copies of English engravings for sale,' declared Gambart. ${ }^{15}$ In his criticism of English legislation, Gambart often pointed to French legislation as the standard. The French Revolution left its mark in the field of intellectual property, as in many other aspects of society. The traditional privilege system, closely associated with the guild structure and censorship of the Ancien Régime, was overthrown and the rights of individuals were affirmed in the Déclaration des Droits de l'homme et du citoyen (1789). Soon the recognition of the individual was translated into that of the artist, as can be interpreted from a decree from 1793, which proclaims in article 3: 'Les auteurs d'écrits en tout genre, les compositeurs de musique, les peintres et dessinateurs qui feront graver des tableaux ou dessins, jouiront, durant leur vie entière, du droit exclusif de vendre, faire vendre, distribuer leurs ouvrages dans le territoire de la République, et d'en céder la propriété en tout ou en partie.16 The droit de reproduction soon became an accepted right in the French art world, as described in L'Artiste in $1839 .{ }^{17}$ The droit de reproduction provided the legal basis for artists to enjoy commercial benefits from the reproduction of their work. However, to enjoy copyright protection the artist needed to stay apprised of his rights. Inattention could result in their loss, which sorely irritated the renowned painter Horace Vernet, who fiercely resisted this prospect in his essay Du droit des peintres et des sculpteurs. Sur leurs ouvrages (1841). ${ }^{18}$

The national orientation of copyright legislation soon proved to be a complex limitation in the international art market and print business, as experienced

14 Related to copyright, the patent laws were relevant for the arts-and-crafts, but this interesting topic falls outside the scope of this article. See for discussions concerning patents in relation to the arts and industry: Elizabeth Bonython and Anthony Burton, The Great Exhibitor: The Life and Work of Henry Cole (London: V\&A Publications, 2003), 109-11.

15 Ernest Gambart quoted in Hamber, 'A Higher Branch of the Art,' 212.

16 Décret des 19-24 juillet 1793 (an II de la République), art.1. A previous decree from January 1791 guaranteed the author's supervision and income with regard to the production of plays. See: décret des 13-19 janvier 1791, art.3: 'Les ouvrages des auteurs vivants ne pourront être représentés sur aucun théâtre public, dans toute l'étendue de la France, sans le consentement formel et par écrit des auteurs, sous peine de confiscation du produit total des représentations au profit des auteurs.' For this decree of 1793 see also: Anne L. Schroder, "Reversals of Power: Artistic Property, Counterfeiture, and the 1793 French Copyright Act," Visual Resources 16 (2000): 143-54.

17 François Lecler and Léon Noel, "Revue des éditions illustrées, des gravures et des lithographies," L'Artiste (1839): 142.

18 Horace Vernet, Du Droit des Peintres et des Sculpteurs sur les ouvrages (Paris: Édouard Proux, 1841), 8. 
by the internationally operating art dealer and print publisher Ernest Gambart. Piracy of printed works was a phenomenon that crossed national borders. ${ }^{19}$ At the same time the international art market and print business in the nineteenth century was hindered by national legislations. As a result, national copyright laws were supplemented by a series of bilateral treaties intended to provide more international protection for intellectual property. ${ }^{20}$ This was followed by efforts to achieve a multilateral regulation of copyrights. ${ }^{21}$ On 9 September 1886 the Berne Convention was signed by ten countries, including England, France and Germany. It established a permanent jurisdiction of international law, guaranteeing participating countries a basic level of protection of intellectual property, which was accorded to the author for a period of up to thirty years after his death. ${ }^{22}$ This treaty provides the legal basis for national and international copyright protection to this day.

\section{Save Our National School of Engraving!}

On 1 February 1859 the leading printmakers Henriquel-Dupont, Adolphe Mouilleron, Léon Noël and the publisher Goupil submitted a petition to Napoleon III. They requested protection for traditional reproduction techniques against the threat of technical innovations such as photography. ${ }^{23}$

19 Gambart pointed accusingly to German publishers whose widespread distribution of large volumes of illegal reproductions not only had negative effects in other European countries but also in Germany itself, see: Ernest Gambart, On Piracy, 17. For centuries there had been a strong tradition in the Netherlands of reprinting foreign works, a practice that continued in the nineteenth century.

20 Henri Louis de Beaufort, Het Auteursrecht in het Nederlandsche en internationale recht (Utrecht: De Boer, 1909), 65-6. Particularly France made a number of bilateral agreements with various (neighbouring) countries in order to secure legal protection for its authors abroad. In $185^{2}$ France signed a treaty with England, followed by treaties with Spain (1853), the Netherlands (1855), Denmark (1858), Russia (1861), Prussia (1862) and Austria (1866).

21 Frederik Willem Grosheide, Auteursrecht op maat (Deventer: Kluwer, 1986), 275-6.

22 This international treaty assumed that each participating country had already introduced a basic national law concerning copyright. Founded in 1886 by ten countries, the Berne Convention has 168 contracting nation states today. See: http://www.wipo.int/treaties/ en/ShowResults.jsp?treaty_id $=15$. For extensive information on international authorship rights, see: Jaap H. Spoor en Dirk W.F. Verkade, Auteursrecht (Deventer: Kluwer, 1993), $525-44$.

23 Verhoogt, Art in Reproduction, 105. For various contributions on this subject, see: André Rouillé, La Photographie en France. Textes \& Controverses: une Anthologie 1816-1871 (Paris: Éditions Macula, 1989), 298-309. For this petition, see also: Pierre Renié, "The Battle for a Market: Art Reproductions in Print and Photography from 1850-1880," in Intersections: 
While these technological innovations in art reproduction offered new possibilities for the future, they also caused concerns over the possible decline of rich cultural traditions. Furthermore, the national school of engraving was also threatened by the abundance of cheap prints from abroad. ${ }^{24}$ The traditional engraving technique was a French cultural tradition based on the methods used by famous engravers of the seventeenth century. The petition honoured the engraving technique as a valuable part of French cultural heritage in need of protection, but it also requested that the French government provide patronage to compensate for the failing market. They argued that the national tradition of the art of engraving had to be maintained, if necessary at the expense of technical innovation.

This appeal to save traditional techniques illuminates an awareness that increasingly resounded in various commentaries during the 1850 s and 1860 os. In 1863 , for example, critic Philippe Burty wrote about the prints displayed at the Salon: 'La photographie tuera la gravure.'25 The rich cultural tradition of engraving, with its roots in the fifteenth century, would soon be over. Engraving had been 'murdered' by photography, according to Burty, and he was not the only one with this opinion. ${ }^{26}$ Of course, there was not a singular causal relation between the success of photography and the downfall of the state of engraving. Instead, it was a matter of production costs, a backslide in commissions and expertise, and a change in the markets in graphic and photographic reproductions. The 186os appeared to be a complex and critical phase of the history of engraving. Interestingly, as Burty underlined in 1861, 'Le burin est un art essentiellement national. ${ }^{27}$ Because the art of line engraving was considered national cultural heritage, printmakers and publishers turned to the state to save the French school of engraving.

Lithography, Photography and the Traditions of Printmaking, ed. Kathleen Stewart Howe (Albuquerque: University of New Mexico Press, 1998), 44-5.

24 The Dutch print business showed the same concerns in the 1830 s about the fragile national print tradition threatened by the abundance of cheap prints from abroad. See: Verhoogt, Art in Reproduction, 74-6.

25 Philippe Burty, "La gravure et la lithographie. Salon de 1863," Gazette des beaux-arts (1863): 147. Gautier had initially stressed that the latest medium was a welcome addition to the world of art reproduction and of service to art in general. See: Théophile Gautier "Exposition Photographique," L'Artiste (1857): 194. See for more about the endangered art of engraving in the 1860s: Verhoogt, Art in Reproduction, 105-8.

26 See also: M. de Saint-Santin, "De Quelques arts qui s'en vont," Gazette des beaux-arts (1865): 305 and 316.

27 Philippe Burty, "La gravure et la lithographie à l'exposition de 1861," Gazette des beaux-arts (1861): 172 . 
The French state had a strong tradition of patronage in printmaking, from the reign of Louis XIV until well into the nineteenth century, with publications such as Le grand ouvrage de l'Égypte, Le Sacre de Napoléon, l'Iconographie grecque et romain and Le Sacre de Charles $x$. The establishment of the new permanent Académie des Beaux-Arts in 1816, supported by painters, sculptors, composers and engravers, was also meant to stimulate the economy in the arts. ${ }^{28}$ However, the stormy political developments of the Restoration and the July Revolution were followed by the reign of the liberally inclined, bourgeois King Louis-Philippe (r. 1830-48), which subsided a stream of government-sponsored projects. ${ }^{29}$ The connection between the state and printmaking was no longer self-evident, but it was never entirely severed during the nineteenth century either. In the 1830 s and 1840 s, for example, there were recurring appeals to the state to protect the traditional and esteemed art of printmaking. L'Artiste repeatedly underlined the government's responsibility for traditional engraving, on the one hand, and the dangers of the commercial market, on the other. For example, in 1837: 'Sous le rapport commercial, cet art mériterait donc la protection du gouvernement' (italics added). ${ }^{30}$ Where the government failed to act, engraving was left to the mercy of the market. One example of the French state's involvement in printmaking was Napoleon III's 1853 project to reorganise the Chalcography Department at the Louvre - where major artworks were reproduced in print—in imitation of Louis XIV's earlier

28 Harrison C. and Cynthia A. White, Canvases and Careers: Institutional Change in the French Painting World (Chicago and London: Chicago University Press, 1993), 16-8. The French Académie de Peinture et Sculpture was a source of inspiration for the establishment of the Royal Academy of Arts in the Netherlands as part of a new educational system that aimed to revive the cultural glory of the past and to train artists and draughtsmen in order to stimulate national economic developments in architecture, manufacture, and arts and crafts. The founding of the Academy of Scotland in Edinburgh was also strongly influenced by the economic ideas first articulated by the former Edinburgh resident Adam Smith, see: Jenny Reynaerts, 'Het karakter onzer Hollandsche School.' De Koninklijke Akademie van Beeldende Kunsten te Amsterdam, 1817-1870 (Leiden: Primavera Press, 2001), 55; Duncan Forbes, "Private Advantage and Public Feeling: The Struggle for Academic Legitimacy in Edinburgh in the 1820s," in Art and the Academy in the Nineteenth Century, eds. Rafael Cardoso Denis and Colin Trodd (Manchester: Manchester University Press, 2000), 86-101.

29 Annick Bergeon, "Le temps ciselé, correspondances autour d'une œuvre gravée: éditeurs, artistes, critiques (1829-1859)," in États des lieux, ed. Hélène Lafont-Couturier, vol. 1 (Bordeaux: Musée Goupil, 1994), 83.

Anon., "De la gravure," L'Artiste 14 (1837): 287-9. 
initiative. ${ }^{31}$ During the 1860 s the French government decided to commission reproductions of paintings in government buildings and churches. Thus new prints were ordered by the French state, which, as The Art Journal stated in 1862, 'seems to have become alarmed at the state of line engraving, and is now determined to support it by all means in its power.'32

The mezzotint was to English printmaking what line engraving was to the French. The origins of the method lay in the Low Countries, but it was perfected in England and soon became known as the 'maniera anglais.' ${ }^{33}$ Mezzotint was an exceptionally successful reproductive technique, employed on a large scale during the golden age of English printmaking in the late eighteenth century. Renowned mezzotinters, such as James MacArdell (1728/29-65), Valentine Green (1739-1813) and John Raphael Smith (1752-1812), made Sir Joshua Reynolds one of the most reproduced artists of his age. ${ }^{34}$ While French printmakers of the early nineteenth century pursued the tradition of seventeenth-century line engravers, English mezzotinters like Charles Turner, William Ward and most importantly Samuel Reynolds (1794-1835) produced many prints after works by celebrated painters in the tradition of the 'Great Age of the Mezzotint. ${ }^{35}$

31 Arthur. M. Hind, A History of Engraving \& Etching from the 15th Century to the Year 1914 (New York: Dover Publications, 1967), 198. See also: Henry de Chennevières, "Exposition Universelle de 1889. La gravure du siècle au Champ de Mars," Gazette des beaux-arts (1889): 483; Elizabeth Anne McCauley, Industrial Madness: Commercial Photography in Paris, 1848-1871 (New Haven: Yale University Press, 1994), 279.

32 Anon., "Minor Topics of the Month," The Art Journal (1862): 88.

33 Gerdina Wuestman, "De Hollandse schilderschool in prent. Studies naar reproductiegrafiek in de tweede helft van de zeventiende eeuw" (Phd diss., Universiteit Utrecht, 1998), 125 .

34 During Reynolds's lifetime hundreds of mezzotints were made after his work, particularly his portraits. Other artists whose work generated many prints were Thomas Gainsborough, George Romney, Allan Ramsay and Joseph Wright of Derby. Line engravings were also produced in England, in the shadow of the many mezzotints. For example, Hogarth's famous moralising genre series, such as A Harlot's Progress and A Rake's Progress, were largely reproduced as line engravings, although this may be explained by the fact that Hogarth tended to work with French engravers: David Bindman, Hogarth and his Times: Serious Comedy (London: British Museum, 1997), 31.

35 The Salons of 1810 and 1812 had already exhibited prints by Reynolds after French masters such as Delaroche and Géricault, which the Englishman had produced during a stay in Paris in 1809. He also stayed in the French capital for some time in the mid-1820s. Reynolds probably spent a total of five or six years in Paris, on the advice of English publishers who had set up branches in the city: Carol Wax, Mezzotint: History and Technique (New York: Abrams, 1996), 100. 
In England equal concerns existed about the future of traditional engraving. ${ }^{36}$ In 1850 John Burnet, the grand old man of English engravers, had already foreseen the demise of English engraving. ${ }^{37}$ Renowned English engravers like Charles William Sharp (1818-99), George Thomas Doo (1800-86) and John Pye (1782-1874) had become a rarity. ${ }^{38}$ In contrast to the French state, the English government generally kept its distance from (the reproduction of) art. When a special House of Commons committee investigated the position of English printmaking in 1836, engraver John Pye declared: 'as far as I know, except for a few private patrons, no encouragement is extended to art, besides that which comes through the printsellers. ${ }^{39}$ The English state, unlike the French, did not systematically stimulate the art of engraving with commissions. On the contrary, Queen Victoria and her husband, Prince Albert, did encourage photography - the engravers' "enemy." Prince Albert, in particular, showed a great interest in the new medium and even initiated a comprehensive "catalogue raisonné" with reproductions of Raphael's work, entitled Works of Raphael Santi da Urbino as Represented in the Raphael Collection in the Royal Library at Windsor Castle, Formed by H.R.H. The Prince Consort 1853-186r and Completed by Her Majesty Queen Victoria. An imposing publication, it contained a number of prints and no less than 2,00o photographs.

The critic Louis Clément de Ris also recognised the differences between English and French graphic arts and likewise had an eye for the merits of printmakers on the other side of the Channel. While English printmakers continued to live up to their reputation in the field of mezzotint and wood engraving, French engravers were superior in the field of line engraving. ${ }^{40}$ Nevertheless, both in France and England- the two superpowers in the graphic worldconcerns were now growing about the uncertain future of traditional printmaking. The French government was especially active in addressing the need to protect the national school of engraving for the future and responded with

$36 \quad$ Id., 138.

37 Surveying the production of graphic art in England during the first half of the nineteenth century, Burnet pointed to talented modern engravers such as Doo, Watt and Pye, but also observed that they could not compete with famous English engravers of the past, such as Woolett and Strange. See: Anon., "Autography of John Burnet," The Art Journal (1850): 275-7.

38 Anon., "Line-engraving," The Art Journal (1864): 354. See also: Anon., "Line Engraving," The Art Journal (1866): 158 .

39 John Pye, Evidence Relating to the Art of Engraving Taken Before the Select Committee of the House of Commons, on Arts, 1836, and the Committee's Report Made to the House Thereon (London: s.n., 1836), 38 .

$40 \quad$ Louis Clément de Ris, "Salon de 1859. Gravure et lithographie," L'Artiste 7 (1859): 98. In 1861 Philippe Burty wrote in a similar vein on the subject of French engraving: Burty, "La gravure et la lithographie," 172. 
several projects to save the endangered technique. It is difficult to retrospectively determine to what extent these initiatives were effective and actually changed the course of the history of engraving. However, it clearly shows a national dimension to the business of engraving. Of course, the state's role in patronage was not self-evident. Despite equal doubts concerning the uncertain future of engraving in England and France, the response of their governments was different. The active participation of the French government as a patron was largely absent across the Channel.

\section{"Authentic" National Publications}

'Une idée de génie [...] graphique' was the response to the plan proposed by engraver Pierre Laurent (1739-1809) to reproduce all the paintings and sculptures in the French royal collection in print, and thereby breathe new life into French printmaking. ${ }^{11}$ The Musée Français, recueil complet des tableaux, statues et bas-reliefs qui composent la collection nationale was published between 1803 and 1811 with contributions by dozens of engravers. It was continued by Laurent's son, Pierre Louis Henri Laurent (1779-1844), under the title Musée Royal and published between 1816 and 1822 (Fig. 9.2). ${ }^{42}$ This publication of prints by the Laurents was honoured as a national publication, but it was a private and commercially driven project.

"National" publications, either in name or ambition, were not the exclusive domain of national institutions. Commercial print dealers also used this description in their marketing strategies to reach their public. Here, I would like to consider the terms "nation" and "nationalism" in the marketing of engravings. As mentioned above, sometimes dealers were blamed for the decline of the state of engraving. ${ }^{43}$ However, L'Artiste also published more liberal-minded ideas that highly valued the role played by commercial art dealer-publishers like Goupil. ${ }^{44}$ In the Netherlands the important art dealer-publisher Frans

41 Henry de Chennevières, "La gravure du siècle," Gazette des beaux-arts (1889): 480. See also: Verhoogt, Art in Reproduction, 69-71.

42 The Musée Francais was published in four folio albums, containing a total of 344 prints. The Musée Royal comprised two folio albums with 161 prints. For the latter, see also: Anon., "De la gravure," L'Artiste 14 (1837): 288; Henri Delaborde, La Gravure. Précis élémentaire de ses origines, de ses procédés et de son histoire (Paris: A. Quantin, 1882), 269. See also: Stanley William Hayter, New Ways of Gravure (London: Routledge \& Paul Kegan, 1968), 187 .

43 Anon., "Gravures et lithographies," L'Artiste 4 (1843): 122.

44 A.J., "Simples réflections sur l'art et les artistes," L'Artiste (1835): 236-8. 
L E

\section{MUSEE FRANCAIS,}

\section{RECUEIL COMPLET \\ 'DES}

\section{TABLEAUX, STATUES ET BAS-RELIEFS,}

QUI COMPOSENT LA COLLECTION NATIONALE;

Avec Pexplication des Sujets, et des Discours historiques sur la Peinture, la Scalptare et la Gravure,

PAR S.G CROZE-M AGNAN.

PUBLIE

\section{PAR ROBILLARD-PERONVILLE ET LAURENT.}

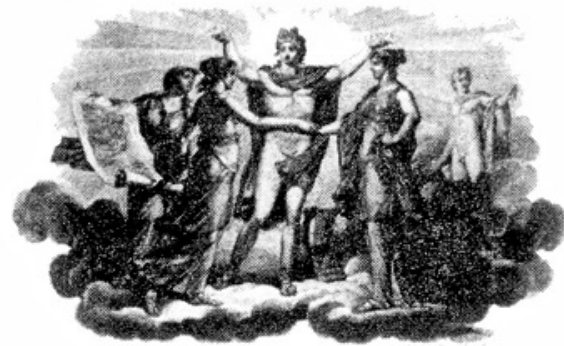

PA R IS,

DE LIMPRIMERIE DE L.-E. HERHAN.

$\mathbf{x} .=\mathbf{x} 803$.

FIGURE 9.2 Simon-Célestin Croze-Magnan, Louis-Nicolas-Joseph Robillard-Péronville, Pierre Laurent, Le Musée Français. Recueil complet des Tableaux, Statues et Bas-reliefs, qui composent la collection nationale, vol. 1 (Paris: L.-É. Herhan, 1803), frontispiece 
Buffa was admired for his continuing efforts to promote the art of engraving. ${ }^{45}$ Buffa was established in Amsterdam in 1806 and soon thereafter became one of the leading firms in the Dutch print business. ${ }^{46}$ During the nineteenth century the firm produced prints after old masters like Rembrandt and Bartholomeus van der Helst and fashionable modern painters like Jozef Israëls, singular prints and large-scale exclusive albums about the Rijksmuseum and Dutch history and its colonies.

Buffa repeatedly sent his prospectus and new prints for subscription to King William III. ${ }^{47}$ These prints were for sale and not intended as gifts, not even for the king. Instead, Buffa's motivation was to persuade the king to support his publications. In this context Buffa often used words like 'nation' and 'national' in his patriotic approach to His Majesty, as in his letter of 6 July 1871. In humble words Buffa presented his latest publications to the king, hoping for subscription. The publisher underlined that his publications were always of 'national artistic importance,' whether they were prints after modern painters like Israëls and Rochussen, or after Rembrandt or Van der Helst. For over fifty years the firm had published editions of national importance, according to Buffa himself. ${ }^{48}$ Repeatedly, Buffa underlined his ambition to publish paintings by Dutch painters engraved by Dutch engravers to make their works better known to everyone ${ }^{49}$ Buffa explained his national ambitions in relation to a couple of new engravings after Charles Rochussen in his letter to King William III of April 1873. It was an honour 'to present the first prints of this new Dutch work of art. Being aware that art is one of the most powerful instruments to stimulate good taste and civilisation, we have stated it our mission in life to, as far as our weak forces may reach, promote the national art, to make it better known and distribute it. Being not unsuccessful in this mission, we are so thanks to the positive attention our efforts attracted in this country and abroad. 50

45 Anon., "Kunstberichten," De Kunstkronijk 8 (1847): 14.

46 Jan Frederik Heijbroek, "Van eenvoudige prentenkoopman tot gerenommeerde kunsthandelaar: Frans Buffa \& Zonen in Amsterdam (ca. 1785-1951)," De Boekenwereld 23, no. 2 (2006): 50-66; Sylvia Alting van Geusau, Mayken Jonkman, and Aukje Vergeest, eds., Schoonheid te koop. Kunsthandel Frans Buffa \& Zonen 1790-1951 (Zwolle: Waanders, 2016).

47 I want to thank Sylvia Alting van Geusau for bringing this correspondence to my attention. These letters are kept in the Koninklijk Huisarchief in The Hague. See also: Robert Verhoogt, "De firma Frans Buffa \& Zonen: handelaar in prenten," in Schoonheid te koop, 67-79.

48 Koninklijk Huisarchief, The Hague, Letter from Buffa to the secretary of King William III, 6 July 1871 .

49 Koninklijk Huisarchief, The Hague, Letter from Buffa to King William III, 9 February 1865.

5o Koninklijk Huisarchief, The Hague, Letter from Buffa to King William III, April 1873. 
A "national" publication par excellence that Buffa was proud to present to King William III was the first issue of Nederland in de XVI \& XVII Eeuw vertegenwoordigd zijne groote mannen; door J.W. Kaiser en W.J. Hofdijk, stating in a letter of 17 February 1857: 'All our strength and ambition have been applied in order to make this issue completely Dutch and worthy enough regarding the subject it presents. ${ }^{51}$ The same day the publisher wrote to the private secretary of the king pointing to the high costs of this expensive production and hoping for the king's support. ${ }^{52} \mathrm{~A}$ few days later Buffa emphasised 'the importance of this work based on our old masters, that the skilful Kaiser and Hofdijk admirably present us our heroes of our history worthy to be part of any collection.53 On 6 March 1857 the king's secretary replied to the publisher that the king had agreed to buy two editions of his publication, one printed on regular paper and the other on Chinese paper. ${ }^{54}$ On 14 March 1857 Buffa sent the sold editions to the king but could not hide his slight disappointment: 'Your Excellency, we cannot deny that we had expected more interest and love to receive from Your Excellency regarding this publication in which Dutch art and history are so honourable and powerful unified. ${ }^{55}$ Buffa's complaint was definitely not appreciated at the court, as we can read in the court secretary's reply. Responding to Buffa's highly inappropriate statement, the secretary felt obliged to explain that, no matter how important the publication might be, it was absolutely not the only one that deserved support. On the contrary, there were many other Dutch publications concerning the arts, literature and sciences that also justified national support. As a result the resources to realise Buffa's project were limited, which ended the affair. ${ }^{56}$ Nonetheless, this publication shows us the way a publisher advertised his "national" publications to the king hoping for support. However, Buffa was not the only one to do so.

Buffa frequently referred to truly "national" publications; to the subject of the publication, which was of national importance, like Dutch history and the arts; or to the Dutch nationality of the engravers and painters involved. Buffa's stock of prints almost completely consisted of national Dutch publications with national subjects or made by Dutch artists. Yet Buffa, like other

$5^{1} \quad$ Koninklijk Huisarchief, The Hague, Letter from Buffa to King William III, 17 February 1857.

$5^{2}$ Koninklijk Huisarchief, The Hague, Letter from Buffa to the secretary of King William III, 17 February 1857 .

53 Koninklijk Huisarchief, The Hague, Letter from Buffa to King William III, 23 February 1857.

54 Koninklijk Huisarchief, The Hague, Letter from the secretary of King William III to Buffa, 6 March 1857.

55 Koninklijk Huisarchief, The Hague, Letter from Buffa to King William III, 14 March 1857.

$5^{6}$ Koninklijk Huisarchief, The Hague, Concept letter from the King's Librarian to Buffa, 16 March 1857 . 


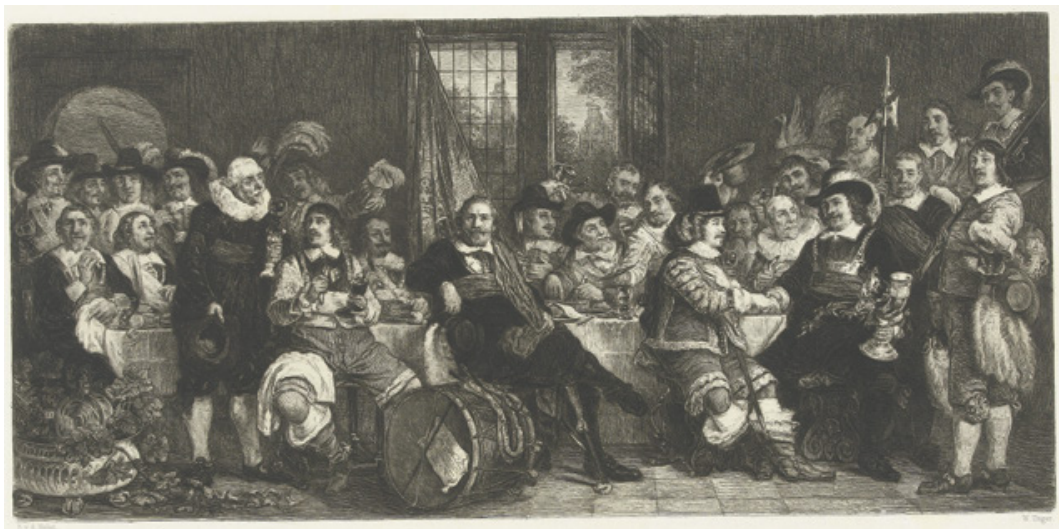

FIGURE 9.3 William Unger after Bartholomeus van der Helst, Banquet at the Crossbowmen's Guild in Celebration of the Treaty of Münster, 1847-1932. Etching, $26.2 \mathrm{~cm} \times 42.0 \mathrm{~cm}$. Published by F. Buffa \& Zn. Amsterdam, Rijksmuseum

publishers, did work in a very international environment. His stocklist contains well-known Dutch engravers, including Johan Wilhelm Kaiser (18131900) and Hendrik D. Sluyter (1839-1931), but it also includes prints made by the well-known German etcher William Unger (1837-1932) and the French lithographer Adolphe Mouilleron (1820-81). Unger produced a series of etchings after masterpieces at the Rijksmuseum (Fig. 9.3), Mouilleron made a beautiful lithograph after Rembrandt's icon The Nightwatch (Fig. 9.4). The subject of these publications can also be considered national, even though Mouilleron's lithography appears to have been commissioned by the French state.

Of course, the terms "nation" and "national" can be used in many ways in relation to the nineteenth-century print business. From an iconological point of view, subjects from national history had been popular since the late eighteenth century. History and genre paintings by David, Delaroche, Scheffer, and Wilkie depicting scenes from history were very popular at large exhibitions like the Salon and the Royal Academy. This renown was largely echoed in the stocklists of print sellers Goupil, Colnaghi and Buffa. The iconological analysis of nationalism, nineteenth-century history painting and the print business falls outside the scope of this paper. Here I will merely reflect on the observation that the stocklists of internationally operating firms like Goupil, Buffa, Agnew and Colnaghi were dominated by painters and printmakers of the same nationality as their publishers. Buffa provided Dutch publications, Goupil's stock was dominated by French artists and engravers, and Colnaghi's and Agnew's stocks by their fellow Victorian artists. Goupil hardly published any prints 


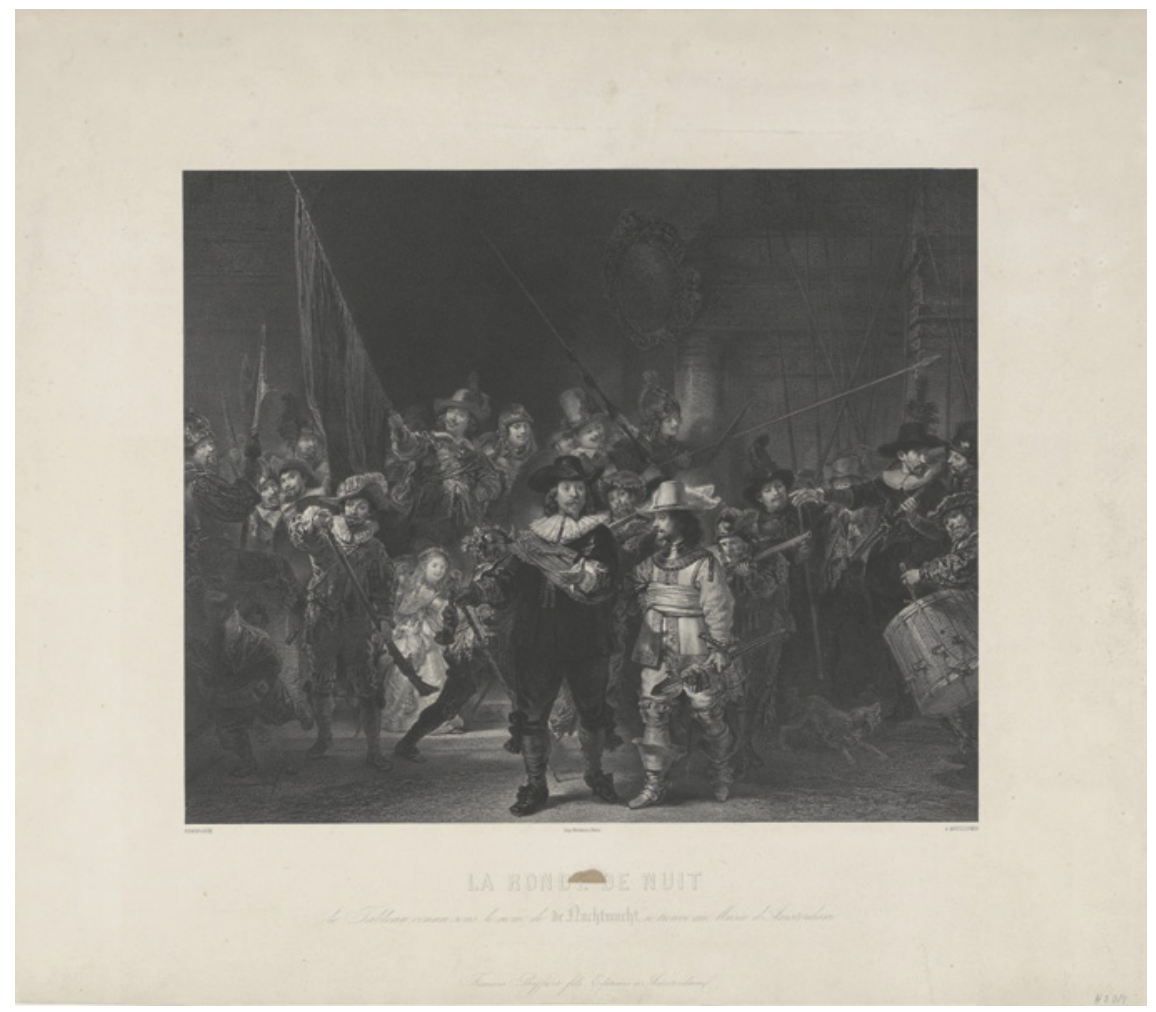

FIGURE 9.4 Adolphe Mouilleron after Rembrandt, The Nightwatch, 1854. Lithography, $39.8 \mathrm{~cm} \times 48.3 \mathrm{~cm}$. Published by F. Buffa \& Zn. Amsterdam, Rijksmuseum

after successful Victorian artists like David Wilkie or John Everett Millais, and neither did Agnew produce engravings after Paul Delaroche. ${ }^{57}$ Although Goupil did publish in the English language, with prints after Constable and Turner, these seem to be the exception to the rule of nationally dominated stocks of these internationally operating dealers. ${ }^{58}$ This is especially striking since the Goupil company was an international network that operated branches in Paris, London, Brussels, The Hague, Berlin and New York for dealing in paintings and prints. Nonetheless, all of these branches used the same stocklists dominated by French Romantic painters of the "juste milieu" and

57 Extrait du Catalogue Général de Goupil \& Cie, Gravures Imprimeurs et Éditeurs, Photogravures Lithographies et Photographies (Paris: s.n., 1877 [1878]).

58 See the 'publications anglaises' in the Catalogue Général de la maison Bousod, Valadon \& Cie éditeurs, successeurs de Goupil et Cie, Gravures, Photogravures, lithographies \& Photographies, Paris, La Haye, Londres, New-York, Berlin, 13-4 and 41-2. 
French printmakers and photographers. This is remarkable considering the international orientation and cooperation of Goupil and their colleagues like Buffa and Colnaghi. But perhaps this observation could be reversed. Maybe these print dealers managed to be successful in an international competitive art print market during the nineteenth century because they were specialised in national artists.

How can we understand these nationally coloured stocklists? Apart from historical and cultural factors, it is interesting to consider these differences from an economic point of view. Admittedly, this is a complex matter to analyse with only fragments of the accountancy of the economic aspects of the print business remaining in our archives today. Nevertheless, it seems plausible that specialisation in the art business could have economic benefits as Adam Smith and especially David Ricardo have shown for other sectors of the economy. In his Principles of Political Economy and Taxation, published in 1817, Ricardo explained the critical role played by differences in production costs in the development of international trade. In his well-known example, Ricardo compared British cloth production with the Portuguese wine industry. He explained the economic benefits of the British specialising in cloth and the Portuguese in wine, and how both countries could profit equally from trading together. ${ }^{59}$ Of course, prints and photographs are different products than cloth and wine, with different production costs. However, it seems reasonable for French art dealer-publishers to specialise in French artists and their work, and for the British to focus on their own domestic art stock because of the cost advantages in the production and reproduction of these works. Obviously, it was easier for British dealer-publishers to deal with their fellow artists, as it was for Frans Buffa to deal with mainly contemporary Dutch artists and engravers. Of course, there are also interesting exceptions to this rule: the Belgian Ernest Gambart was very successful with his French gallery in London, as Goupil was in selling Dutch paintings of the Hague school in Great Britain and the United States. ${ }^{60}$ Nevertheless, considering the stocklists of prints of several successful dealer-publishers, it appears that they focused on artists of their own national schools in order to find success in the international art world. From this perspective the international print market increasingly seems to reflect Ricardo's

59 David Ricardo, Principles of Political Economy and Taxation (London: John Murray, 1817), Chapter 7 .

6o Pamela M. Fletcher, "Creating the French Gallery: Ernest Gambart and the Rise of the Commercial Art Gallery in Mid-Victorian London," Nineteenth-Century Art Worldwide 6, no. 1 (2007), http://www.19thc-artworldwide.org/springo7/143-creating-the-french-galleryernest-gambart-and-the-rise-of-the-commercial-art-gallery-inmid-victorian-london. 
theory of comparative cost differences and international trade in the course of the nineteenth century.

The international networks of Goupil, Buffa and the Victorian print dealers guaranteed the wide circulation of engravings, lithographs, etchings and photographs to an international public of consumers. Prints published in London or Paris could be bought at Buffa's in the Amsterdam Kalverstraat. The international cooperation of dealers can be illustrated by the relationship between the London firm Pilgeram \& Lefèvre and the Amsterdam art dealerpublisher Frans Buffa \& Sons. Pilgeram \& Lefèvre-successor of the illustrious dealer-publisher Ernest Gambart-sold paintings and prints of mainly modern Victorian art from its home base in London, but according to an advertisement these products were also available at the leading Publishers and Printsellers in all countries. ${ }^{\prime 1}$ This simple addendum is interesting because it connects Pilgeram \& Lefèvre's firm to the international market of art dealing and print publishing. The international cooperation of this British firm and Buffa is proven by the fact that some prints after works by the Victorian artist Alma-Tadema, published by Pilgeram \& Lefèvre in 1875, were also available at Buffa in Amsterdam a few months later. ${ }^{62}$ Sometimes Buffa actively promoted the publications of Pilgeram \& Lefèvre to his own regular clients. For example, on 29 March 1874 he proposed King William III the sale of a proof of the 'rightly praised engraving after Alma-Tadema's well-known painting' The Vintage Festival, published by Pilgeram \& Lefèvre. ${ }^{63}$ This print by the famous engraver Auguste Blanchard was one of the finest prints in Pilgeram's stock, published just a few months prior. ${ }^{64}$

Buffa's publications were also available at Pilgeram \& Lefèvre in London. We know that Buffa sold at least one copy of the album Musée National d'Amsterdam: 32 planches gravées à l'eau forte par W. Unger (1875-6) with etchings by Wilhelm Unger to Pilgeram \& Lefèvre. Likewise, Buffa sold his publications to several well-known art dealer-publishers both in the Netherlands and abroad, as seen in Buffa's recently discovered sales book. ${ }^{65}$ The Goupil branch

61 Advertisement L.H. Lefèvre, The Complete Engraved Works of L. Alma Tadema, R.A., Fries Museum, Leeuwarden. See also: Verhoogt, Art in Reproduction, 456.

62 Anon., "Nieuwe uitgaven," De Kunstkronijk (1876): 96; The First Whisper of Love. Companion to "In Confidence," L. Löwenstam, Pilgeram and Lefèvre, 24 December 1875. See: George William Friend, An Alphabetical List of Engravings Declared at the Office of The Printsellers' Association, London, since its Establishments in 1847 to the end of 1885 (London: Printseller's Association, 1886), 77 and 108.

63 Koninklijk Huisarchief, The Hague, Letter from Buffa to King William III, 29 March 1874,

64 Verhoogt, Art in Reproduction, 437-9.

65 https://rkd.nl/explore/archives/details/NL-HaRKD-0554, inv.nr. 12. 
in The Hague bought Buffa's publications on a regular basis, as did the London branch. Other dealers who purchased prints and albums from Buffa were the leading firms Colnaghi and Henry Graves in London and Knoedler in New York.

Buffa sold publications to his colleagues, business to business, or to his local clients at his gallery in the Amsterdam Kalverstraat. Some of his publications were popular amongst an international clientele. Copies of the album Musée National d'Amsterdam were sold to the well-known collector Staats Forbes in London, the industrialist Dagobert Oppenheim in Cologne, railroad entrepreneur Erasmus Gest in Cincinnati and Robert Gordon in Singapore, as well as addresses in Vienna, Berlin, Munich and Basel. Buffa's "national" publications were widely distributed from the Amsterdam Kalverstraat to the corners of the international print market. Commercial dealers like Buffa and his colleagues appear to have been perfectly capable of reconciling their national interests with the international challenges of the art business. In this way Buffa's publications illustrate the refined balance between national and international perspectives in the nineteenth-century art market and print business.

\section{The National Footprint of the International Art Market}

Art dealers, artists, critics and institutions each brought their own "national" perspectives to the internationally booming art business during the nineteenth century. The prominent art dealer-publisher Ernest Gambart claimed national copyright protection; Goupil and the French engravers requested national patronage to save the national school of engraving in France; and finally the Dutch dealer Frans Buffa promoted his publications as "real" national publications and sold them at home and abroad.

The success of firms such as Goupil, Colnaghi and Buffa was based on their print business. After starting as print sellers, they expanded their business to include dealing in paintings and drawings. In the meantime they continued their usual practice of publishing engravings, lithographs and etchings after old and contemporary masters. In this essay I focused on the sale of prints, but of course this business was not completely isolated from the dealing of paintings and drawings. On the contrary. In Buffa's gallery, for example, clients interested in the work of Jozef Israëls could buy paintings, drawings, watercolours and etchings by their beloved master, as well as prints after his works, including engravings, lithographs and etchings in different states, each printed on a different kind of paper and signed by the artist, the printmaker or both. These could be purchased for a variety of prices, framed or unframed. Art and reproductions were one part of a range of products with their own price and 
quality. Likewise, Pilgeram \& Lefèvre offered Alma-Tadema paintings, watercolours and numerous reproductions of his work. Moreover, this firm commissioned paintings from Alma-Tadema at the same time that they assigned engravers and photographers to reproduce them. Auguste Blanchard even engraved Alma-Tadema's The Picture Gallery while the original painting was still on the easel. In many cases artists were just as involved in the reproduction of their own work as they were in creating the original compositions. ${ }^{66}$

Art dealers and artists kept watch over the markets of both paintings and prints. Art and reproduction were held together by legal, artistic and commercial strings. The original painting and the (photo)graphic reproduction proved to be a strong combination in the marketing and promotion of the international art business. For example, the exhibitions of single paintings that toured towns and villages were very popular venues for the promotion and sale of reproductions, like that of William Holman Hunt's painting The Light of the World, which was shown around the world (Fig. 9.5). ${ }^{67}$ It is reasonable, given the close relationship between such paintings and their reproduction, to see the content of the paintings largely matching that of the prints sold by the same art dealer-publishers.

Apart from the similarities in the subject matter of the paintings and prints, there also seem to have been interesting differences between each end of the business. For example, Goupil's international success in selling paintings and drawings of the Hague school artists since the $1870 \mathrm{os}$ is only partly reflected in the stocklist of reproductions published by the firm. ${ }^{68}$ Obviously, paintings and prints are different products with distinct production costs, qualities and prices. The (overlapping) markets of paintings and prints need further research to figure out the different consumption patterns in the (international) art business. The nineteenth-century German statistician Ernst Engel (1821-96) once laid the foundation for the research of consumption patterns. He observed that when incomes rise, people spend relatively less money on food and relatively more money on luxury goods; this is known as Engel's Law. Roughly speaking, during the nineteenth century the consumption of luxury goods generally increased. ${ }^{69}$ Did people buy more prints because they had more money to spend? Or did they buy fewer prints because they could now

66 Verhoogt, Art in Reproduction, 507-24.

67 Jeremy Maas, Holman Hunt and the Light of the World (London: Wildwood House, 1987).

68 Chris Stolwijk, Uit de schilderswereld. Nederlandse kunstschilders in de tweede helft van de negentiende eeuw (Leiden: Primavera Pers, 1998), 216-21; Extrait du Catalogue Général de Goupil \& Cie.

69 For extensive information on the consumption of art and culture, see: Maxine Berg and Helen Clifford, eds., Consumers and Luxury: Consumer Culture in Europe 1650-1850 (Manchester: Manchester University Press, 1999). 


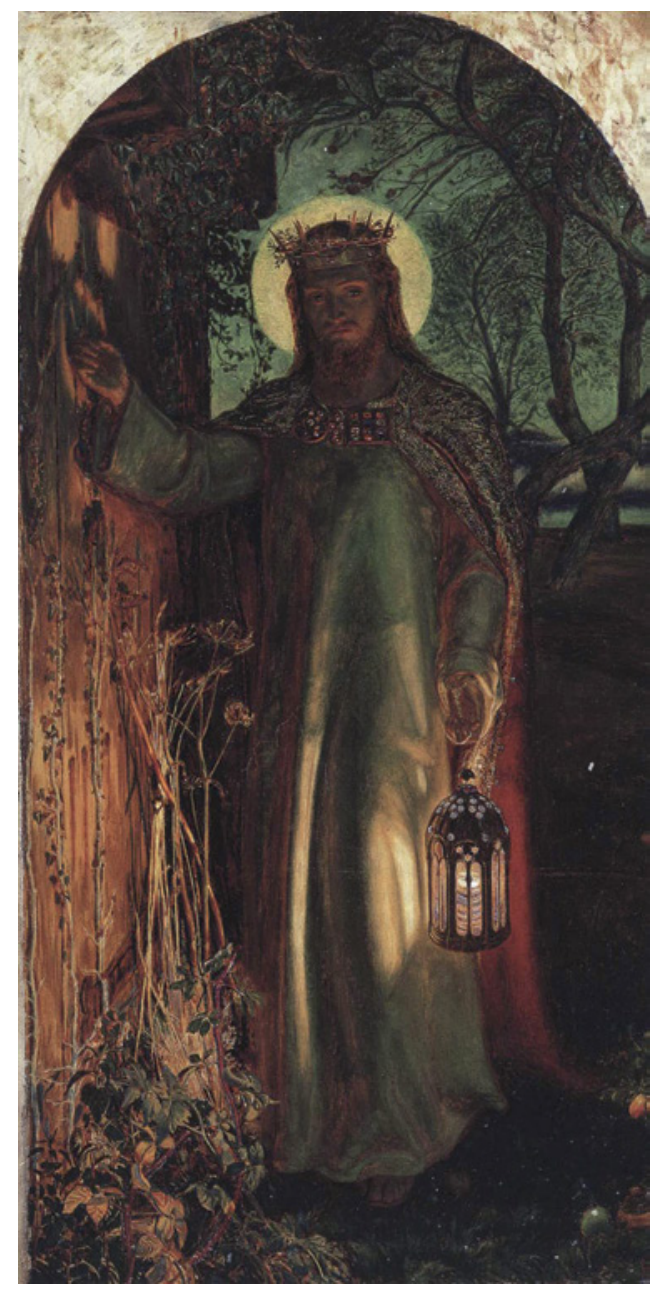

FIGURE 9.5

William Holman Hunt, The Light of the World, $185^{1-56}$. Oil on canvas, $49.8 \times 26.1 \mathrm{~cm}$. Manchester, Manchester Art Gallery

afford paintings in a higher price class? Or did the ratio between the acquisition of paintings and prints remain stable? In other words, were reproductions a substitute for paintings or were they complementary to the original works? More research into nineteenth-century patterns of consumption is required in order to provide a clear answer to these questions. Collecting prints was not a practice limited to people with a restricted budget, for wealthy, elite collectors also purchased reproductions for their exclusive collections. ${ }^{70}$ King William II I did not hesitate to buy prints from Buffa, even though he could afford original

70 Research into print culture in the eighteenth century has shown that prints were also owned by members of the elite. See: Alpheus Hyatt Mayor, Prints and People: A Social History of Printed Pictures (New York: Metropolitan Museum of Art, 1971), 596. 
paintings. So apparently reproductions were not regarded merely as cheap substitutes for paintings. There was a wide public for reproductions, probably wider than that for paintings. This extended from the cultural elite and the social middle classes to the lower sections of society, for whom purchasing a painting was normally above their means. As the Pre-Raphaelite artist F.G. Stephens remarked: 'Where the picture cannot go, the engravings penetrate. ${ }^{71}$

The public of the international art and reproduction market was shaped by both the political economy and private initiatives by artists and entrepreneurs in the art business. International orientation and national interests were complementary elements in the nineteenth-century art business, as can be illustrated by the famous Great Exhibition held in London in 1851. Its initiator, Henry Cole, noted his first discussions with Prince Albert about the event in his memoirs. On 29 June 1849, he asked the prince: 'if the Exhibition should be a National or an International Exhibition [...]. The Prince reflected for a minute, and then said, "It must embrace foreign productions," to use his words, and added emphatically, "International certainly"." ${ }^{2}$ It was up to Cole to decide how much space each country should have at the Great Exhibition, and in the end space was allotted to countries in proportion to their trade with Britain. Therefore, France was given the most space. ${ }^{73}$ So at the Great Exhibition, the footprints of the exhibitors were based on national British interests.

In the international economy of art and reproduction, we come across many references to the nation and nationalism. In many ways national perspectives shaped copyright legislation, public patronage and even the marketing of prints. Copyright legislation thus regulated the art market from a national perspective. When it became clear that this national approach to legal protection was important but not sufficient, international treaties were drafted. The old glorious national tradition of engraving was still cherished in the nineteenth century, but could not guarantee a future unaffected by the invention of new photographic reproductions. And where the art market fell short, artists, printmakers and dealers turned towards the government for patronage to compensate for the art market. Nationally tinged remarks can also be identified in the marketing of prints and "authentic" national publications, like those the publisher Buffa repeatedly used in his letters to promote his publications to

71 Stephens quoted in: Rodney Engen, Pre-Raphaelite Prints: The Graphic Art of Millais, Holman Hunt, Rossetti and their Followers (London: Lund Humphries, 1995), 8.

72 Bonython and Burton, The Great Exhibitor, 116.

73 Id., 140. 
King William III. Buffa promoted his own publications after Dutch paintings and engraved by Dutch printmakers and sold them all over the world. He repeatedly underlined the "national" character of his publications. And in many ways he was right to do so.

\section{References}

A.J. "Simples réflections sur l'art et les artistes." L'Artiste (1835): 236-8.

Alting van Geusau, Sylvia, Mayken Jonkman, and Aukje Vergeest, eds. Schoonheid te koop. Kunsthandel Frans Buffa \& Zonen 1790-1951. Zwolle: Waanders, 2016.

Anderson, Benedict. Imagined Communities: Reflections on the Origin and Spread of Nationalism. London: Verso, 2006.

Anon. "De la gravure." L'Artiste 14 (1837): 287-9.

Anon. "Gravures et lithographies." L'Artiste 4 (1843): 122-4.

Anon. "Kunstberichten." De Kunstkronijk 8 (1847): 14.

Anon. "Autography of John Burnet." The Art Journal (1850): 275-7.

Anon. "International Art Copyright." The Art Journal (1858): 369 .

Anon. "Minor Topics of the Month." The Art Journal (1862): 88.

Anon. "Copyright in Art." The Art Journal (1862): 241.

Anon. "Copyright in Sculpture." The Art Journal (1863): 59.

Anon. "Infringement of Copyright." The Art Journal (1863): 103.

Anon. "Reviews." The Art Journal (1863): 128.

Anon. "Infringement of Copyright." The Art Journal (1863): 210-1.

Anon. "Line-engraving." The Art Journal (1864): 354.

Anon. "Line Engraving." The Art Journal (1866): 158.

Anon. "Nieuwe uitgaven." De Kunstkronijk (1876): 96.

Berg, Maxine, and Helen Clifford, eds. Consumers and Luxury: Consumer Culture in Europe 1650-1850. Manchester: Manchester University Press, 1999.

Bergeon, Annick. "Le temps ciselé, correspondances autour d'une œuvre gravée: éditeurs, artistes, critiques (1829-1859)." In États des lieux, edited by Hélène LafontCouturier, vol. 1, 37-88. Bordeaux: Musée Goupil, 1994.

Bindman, David. Hogarth and his Times: Serious Comedy. London: British Museum, 1997.

Bonython, Elizabeth, and Anthony Burton. The Great Exhibitor: The Life and Work of Henry Cole. London: V\&A Publications, 2003.

Burty, Philippe. "La gravure et la lithographie à l'exposition de 1861." Gazette des beauxarts (1861): 172-9.

Burty, Philippe. "La gravure et la lithographie. Salon de 1863." Gazette des beaux-arts (1863): 147-6o. 
Catalogue Général de la maison Boussod, Valadon \& Cie éditeurs, successeurs de Goupil et Cie, Gravures, Photogravures, lithographies \& Photographies, Paris, La Haye, Londres, New-York, Berlin. 1894.

Chennevières, Henry de. "Exposition Universelle de 1889. La gravure du siècle au Champ de Mars." Gazette des beaux-arts (1889): 478-86.

De Beaufort, Henri Louis. Het Auteursrecht in het Nederlandsche en internationale recht. Utrecht: De Boer, 1909.

Delaborde, Henri. La Gravure. Précis élémentaire de ses origines, de ses procédés et de son histoire. Paris: A. Quantin, 1882.

de Ris, Louis Clément. "Salon de 1859. Gravure et lithographie." L'Artiste 7 (1859): 97-101.

de Saint-Santin, M. “De Quelques arts qui s'en vont." Gazette des beaux-arts (1865): 304-17.

Engen, Rodney. Pre-Raphaelite Prints: The Graphic Art of Millais, Holman Hunt, Rossetti and their Followers. London: Lund Humphries, 1995.

Extrait du Catalogue Général de Goupil \& Cie, Gravures Imprimeurs et Éditeurs, Photogravures Lithographies et Photographies. Paris: s.n., 1877 [1878].

Fletcher, Pamela M. "Creating the French Gallery: Ernest Gambart and the Rise of the Commercial Art Gallery in Mid-Victorian London." Nineteenth-Century Art Worldwide 6, no. 1 (2007), http://www.19thc-artworldwide.org/springo7/143-creat ing-the-french-gallery-ernest-gambart-and-the-rise-of-the-commercial-art-galleryinmid-victorian-london.

Forbes, Duncan. "Private Advantage and Public Feeling: The Struggle for Academic Legitimacy in Edinburgh in the 1820s." In Art and the Academy in the Nineteenth Century, edited by Rafael Cardoso Denis and Colin Trodd, 86-101. Manchester: Manchester University Press, 2000.

Friend, George William. An Alphabetical List of Engravings Declared at the Office of The Printsellers' Association, London, since its Establishments in 1847 to the end of 1885. London: Printseller's Association, 1886.

Gambart, Ernest. On Piracy of Artistic Copyright. London: William Tegg, 1863.

Gautier, Théophile. “Exposition Photographique." L'Artiste (1857): 193-5.

Grosheide, Frederik Willem. Auteursrecht op maat. Deventer: Kluwer, 1986.

Hamber, Anthony J. 'A Higher Branch of the Art': Photographing the Fine Arts in England, 1839-1880. Amsterdam: Gordon and Breach, 1996.

Hamilton, James. A Strange Business: Making Art and Money in Nineteenth-Century Britain. London: Atlantic Books, 2014.

Hayter, Stanley William. New Ways of Gravure. London: Routledge \& Paul Kegan, 1968. Heijbroek, Jan Frederik. "Van eenvoudige prentenkoopman tot gerenommeerde kunsthandelaar: Frans Buffa \& Zonen in Amsterdam (ca. 1785-1951)." De Boekenwereld 23, no. 2 (2006): $5^{0-66 .}$ 
Heilbroner, Robert L. The Worldly Philosophers: The Lives, Times and Ideas of the Great Economic Thinkers. London: Touchstone, 2000.

Hind, Arthur. A History of Engraving \& Etching from the 15th Century to the Year 1914. New York: Dover Publications, 1967.

Hobsbawm, Eric. Nations and Nationalism since 1780. Cambridge: Cambridge University Press, 1992.

Hunt, William Holman. Pre-Raphaelitism and the Pre-Raphaelite Brotherhood. 2 vols. London: Macmillan, 1905.

Lecler, François, and Léon Noël. "Revue des éditions illustrées, des gravures et des lithographies." L'Artiste (1839): 141-3.

Lefèvre, L.H. The Complete Engraved Works of L. Alma Tadema. Advertisement L.H Lefèvre, c. 1888, printed paper, Fries Museum, Leeuwarden.

Maas, Jeremy. Gambart: Prince of the Victorian Art World. London: Barrie \& Jenkins, 1975 .

Maas, Jeremy. Holman Hunt and the Light of the World. London: Wildwood House, 1987.

Mayor, Alpheus Hyatt. Prints and People: A Social History of Printed Pictures. New York: Metropolitan Museum of Art, 1971.

McCauley, Elizabeth Anne. Industrial Madness: Commercial Photography in Paris, 1848-1871. New Haven: Yale University Press, 1994.

Philips, Charles Palmer. The Law of Copyright in Works of Literature and Art and in the Application of Designs. London: V\&R Stevens, Sons and Haynes, 1863.

Pye, John. Evidence Relating to the Art of Engraving Taken Before the Select Committee of the House of Commons, on Arts, 1836, and the Committee's Report Made to the House Thereon. London: s.n., 1836.

Renié, Pierre. "The Battle for a Market: Art Reproductions in Print and Photography from 1850-1880." In Intersections: Lithography, Photography and the Traditions of Printmaking, edited by Kathleen Stewart Howe, 41-53. Albuquerque: University of New Mexico Press, 1998.

Reynaerts, Jenny. 'Het karakter onzer Hollandsche School.' De Koninklijke Akademie van Beeldende Kunsten te Amsterdam, 1817-1870. Leiden: Primavera Press, 2001.

Ricardo, David. Principles of Political Economy and Taxation. London: John Murray, 1817 .

Rosen, Jeff. "The Political Economy of Graphic Art Production During the July Monarchy." Art Journal 48 (1989): 40-5.

Rouillé, André. La Photographie en France. Textes \& Controverses: une Anthologie 18161871. Paris: Éditions Macula, 1989.

Schroder, Anne L. "Reversals of Power: Artistic Property, Counterfeiture, and the 1793 French Copyright Act." Visual Resources 16 (2000): 143-54. 
Smith, Adam. An Inquiry into the Nature and Causes of the Wealth of Nations. Edited by Salvio M. Soares. MetaLibri Digital Library, 2007.

Spoor, Jaap H., en Dirk W.F. Verkade. Auteursrecht. Deventer: Kluwer, 1993.

Stolwijk, Chris. Uit de schilderswereld. Nederlandse kunstschilders in de tweede helft van de negentiende eeuw. Leiden: Primavera Pers, 1998.

Verhoogt, Robert. Art in Reproduction: Nineteenth-Century Prints after Lawrence AlmaTadema, Jozef Israëls and Ary Scheffer. Amsterdam: Amsterdam University Press, 2007.

Verhoogt, Robert. “De firma Frans Buffa \& Zonen: handelaar in prenten." In Kunsthandel Frans Buffa \& Zonen 1790-1950, edited by Sylvia Alting van Geusau, Mayken Jonkman, and Aukje Vergeest, 67-79. Zwolle: Waanders, 2016.

Verhoogt, Robert, and Chris Schriks. "Reflecting Media: A Cultural History of Copyright and the Media." In The Handbook of the History of Information Security, edited by Karl de Leeuw and Jan Bergstra, 83-119. Amsterdam: Elsevier Science, 2007.

Vernet, Horace. Du Droit des Peintres et des Sculpteurs sur les ouvrages. Paris: Édouard Proux, 1841.

Wax, Carol. Mezzotint: History and Technique. New York: Abrams, 1996.

White, Harrison C., and Cynthia A. White. Canvases and Careers: Institutional Change in the French Painting World. Chicago: University of Chicago Press, 1993.

Wuestman, Gerdina. "De Hollandse schilderschool in prent. Studies naar reproductiegrafiek in de tweede helft van de zeventiende eeuw." PhD diss., Universiteit Utrecht, 1998. 